\title{
Product Quality, Quality Services, Price Toward Customer Satisfaction at Indosat Ooredoo
}

\author{
Yugi Setyarko
}

\begin{abstract}
This study aims to determine the effect of product quality, service quality and price to Ooredoo indosat customer satisfaction. The research is based on the increasingly advanced telecommunication industry in Indonesia so that the author realizes the importance of product quality, service and price in creating customer satisfaction. The method used in this research is a quantitative research method that develops and uses mathematical models, theories and / or hypotheses related to the phenomenon around. The purpose of this quantitative study is to test the hypothesis to produce answers to the research of the subject under study. In the primary data collection, the authors use closed questions and in closed questions the authors use the likert scale with a sample of 121 respondents in the population of Indosat Ooredoo customers. In data processing, writer use SPSS 22.0 for windows program and get regression equation from result of analysis of influence of product quality, service and price to Indosat Ooredoo customer satisfaction. Based on the research results prove, both partially and simultaneously, research reject Ho and accept Ha. So it can be concluded that product quality, service and price variables have a positive and significant effect on customer satisfaction of Indosat Ooredoo.
\end{abstract}

INTRODUCTION

\section{A. Research Background}

The world of telecommunications in this era of globalization is increasingly advanced. The large number of GSM card product products makes Indosat Ooredoo companies face an era of competition [1]. The biggest challenge faced by the company today is how to build customer satisfaction to win the competition because the customer is an important factor in the success of a company. In the advanced companies, customers are the main target to note. Companies should be able to provide the best quality in products and services in accordance with the needs and desires of customers so that the product can provide satisfaction for its customers [2].

In addition to requiring product quality products, quality of service is also required in meeting customer satisfaction. The quality of this service has become an important aspect as it will have a direct impact on Indosat Ooredoo's corporate image. Good service quality will be an advantage for the company [3]. The commitment of the company in providing services is needed, one of which is the seriousness that contains elements of

Revised Manuscript Received on July 05, 2019.

Yugi Setyarko,

Faculty Economics and Business, Universitas Budi Luhur

1yugi.setyarko@budiluhur.ac.id friendliness, courtesy and speed of responsiveness given to its customers, so that customers feel spoiled by the best service provided by the company Indosat Ooredoo [4]. The number of price competition faced by operators in Indonesia, making Indosat Ooredoo feel challenged to set a very cheap price. Indosat Ooredoo offers low-cost, simple and uncomplicated tariff schemes, where tariff products are highly transparent without time and day segments. With this in mind, Indosat Ooredoo expects to meet the needs and satisfaction of its customers [5-6].

\section{B. Problem Identification}

1. To study whether there is a partial effect of product quality toward customer satisfaction

2. To study whether there is a partial effect of Product Quality on customer satisfaction

3. To study whether there is a partial price effect on customer satisfaction

\section{Research Framework}

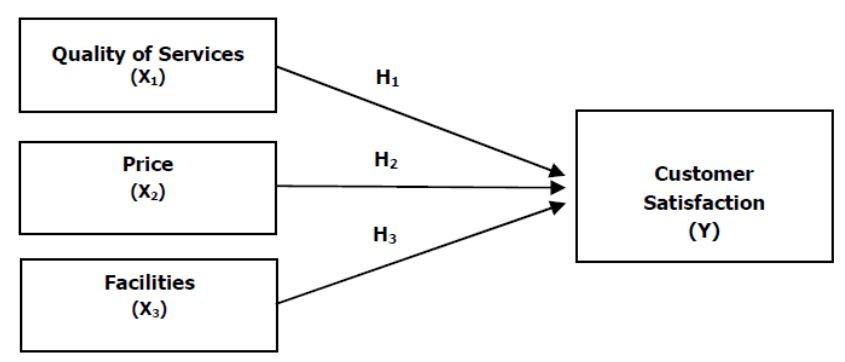

Figure 1. Framework

Research Framework

Hypothesis

Hypothesis testing partially between product quality (X1) to customer satisfaction (Y)

$\mathrm{H}_{1}$ : There is a partial effect of product quality on Customer Satisfaction.

Hypothesis testing partially between service quality (X2) to customer satisfaction (Y)

$\mathrm{H}_{2}$ : There is a partial effect of Progiuct Quality ô, satisfaction. 
Hypothesis testing partially between price (X3) to customer satisfaction (Y)

\section{$\mathrm{H}_{3}: \quad$ There is a partial price effect oncustomer}

\section{LITERATURE REVIEW}

\section{A. Marketing Management}

According to Kotler and Keller (2009), marketing is to identify and meet the needs of the human and social through the Exchange process. while according lupiyoadi (2014), marketing management is an analysis of the planning, implementation and control program - programs that have planned in conjunction with the Exchange of favorable to the buyer target with a view to achieve the goals the organization.

\section{B. Product Quality}

According to tjiptono (2014), the product is everything that can be offered manufacturer to note, asked, look, purchased, use, or consumed market as the needs or desire market is concerned. products offered include goods physical, services, people or personal, where, organizations, and ideas. while according Kotler and Armstrong (2008), the quality of the product is the ability of a product to perform their functions which includes durability, reliability, accuracy, ease, operations and repair and the other attributes. 2.3 service quality according tjiptono (2014), the service is an effort needs and desires consumers as well as the accuracy of delivery in offset consumer expectations.

\section{Price}

Price Definition by Kotler \& Armstrong (2008), Price is the sum of money that is billed on a product or service, or the amount of value exchanged by customers to benefit from owning or using a product or service.

\section{Customer satisfaction}

Fandy Tjiptono (2014) defines that customer satisfaction is an emotional response to an evaluation of the consumption experience of a product or service.

\section{RESEARCH METHODOLOGY}

Dependent variable in this research is customer satisfaction (Y). The independent variables in this research are product quality (X1), service quality (X2), price (X3). For the population in this study were Indosat Ooredoo customers. Sampling technique used is sample ramdom sampling, which is random without paying attention to strata in the population. Respondent's opinion gathering is done by using koesioner through google form application. During the process of distributing questionnaires, participation of 121 respondents was classified as primary data. The collected data is then tested using SPSS Statistic 22.0 software to find out whether the data is feasible enough to be analyzed and whether the data analysis results adequately represent the actual state. The test consisted of validity test, reliability test, multicollinearity test, and heteroskodasticity test. Subsequently, the test passing data were analyzed using correlation method, linear

Revised Manuscript Received on July 05, 2019.

Yugi Setyarko,

Faculty Economics and Business, Universitas Budi Luhur

1yugi.setyarko@budiluhur.ac.id regression, $\mathrm{f}$ test, model reliability test ( $\mathrm{t}$ test) and determinant coefficient test.

\section{A. Research Object}

PT Indosat, Tbk is one of Indonesian companies engaged in telecommunication services. The company was established on November 20, 1967. PT Indosat Tbk., Formerly known as PT Indonesian Satellite Corporation Tbk., Is a company engaged in telecommunication service providers based in Indonesia. Indosat itself provides telecommunications services in the form of mobile communications based on prepaid and postpaid, fixed telecomm, and Global Corporate Services. Its products are very familiar with Indonesian ears, such as IM3, IM2, Matrix, Star-one, and Mentari. And in november 2015, Indosat changed their brand name to Indosat Ooredoo. Indosat took up to two years until finally chose to change the company name and logo to Indosat Ooredoo. Indosat which is now one of the operators under the auspices of the ooredoo group of Qatar. However, the name of Indosat is maintained in the identity of this new company. In contrast to other subsidiaries owned by Ooredoo around the world.

\section{B. Research Model}

\section{1) Simple Random Sampling}

Simple random sampling method, said simple because according to Sugiyono (2015) is taking the sample of the population is done randomly without regard to the strata in the population, such way is done when members of the population is considered homogeneous.

\section{2) Validity and Realibility Tests}

According to Husein Umar (2014), validity is useful to know if there are any questions on the questionnaire that should be discarded or replaced because it is considered irrelevant. Meanwhile, according to Husein Umar (2014) reliability is useful to determine whether the instrument in this case the questionnaire can be used more than once, at least by the same respondent.

\section{Classical Assumption Tests \\ 1) Normality Tests}

According to Imam Ghozali (2009), said that the Normality Test aims to test whether in the regression model, the intruder or residual variable has a normal distribution.

\section{2) Multicolinearity Tests}

Imam Ghozali (2009), suggests that Multicolinearity test aims to test whether the regression model found the existence of collation between independent variables.

\section{3) Heteroscedasticity Test}

Imam Ghozali (2009), suggests that the Heteroskidity test aims to test whether in the regression model there is a variance inequality of the residual one observation to another observation.

\section{Hypothesis Testing}

According Sugiyono (2015), the hypothesis is a temporary answer to the

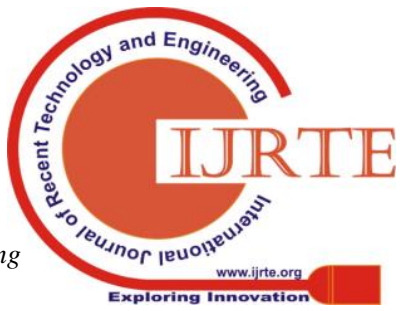


formulation of the problem so it needs to do hypothesis testing. This test is done with 2 significance test, that is $t$ test and model reliability test.

\section{E. Linear Regression Test}

According to Umar (2007), linear regression is a measuring instrument used to measure the presence or absence of influence between variables. where the dependent variable $(\mathrm{Y})$ is connected or explained more than 1 variable may be 2.3, and so on the independent variables (X1, X2, X3,) but still show the linear relationship diagram.

\section{F. Determinant Coefficient Test}

Test $\mathrm{R}^{2}$ or test of determination is an important measure in regression, because it can inform whether or not the regression model is estimated, in other words the number can measure how close the regression line is estimated with the actual data. The value of the coefficient of determination (R2) reflects how large the variation of the bound variable $\mathrm{Y}$ is explained by the independent variable $\mathrm{X}$.

\begin{tabular}{|c|c|c|c|c|c|}
\hline \multirow{2}{*}{$\begin{array}{r}\text { M } \\
\text { odel }\end{array}$} & \multicolumn{2}{|c|}{$\begin{array}{c}\text { Unstandar } \\
\text { dized } \\
\text { Coefficients }\end{array}$} & \multirow{2}{*}{$\begin{array}{c}\begin{array}{c}\text { Standardize } \\
\mathrm{d}\end{array} \\
\text { Coefficients } \\
\text { Beta }\end{array}$} & \multirow{2}{*}{$\mathrm{t}$} & \multirow{2}{*}{ ig. } \\
\hline & B & $\begin{array}{c}\text { S } \\
\text { td. } \\
\text { Error }\end{array}$ & & & \\
\hline (Cons & $\begin{array}{r}- \\
3.101\end{array}$ & $.200^{1}$ & & $\begin{array}{r}- \\
2.584\end{array}$ & $011^{\circ}$ \\
\hline Prode & $94^{.3}$ & 065 & .439 & $023^{6 .}$ & 000 \\
\hline Quali & $16^{.2}$ & $048^{\circ}$ & .286 & $524^{4 .}$ & $000^{\circ}$ \\
\hline Price & $87^{.2}$ & $077^{\circ}$ & .261 & $747^{3 .}$ & $000^{\circ}$ \\
\hline
\end{tabular}

Table 1 : Linear Regression Testing Coefficients ${ }^{\mathrm{a}}$

Linear regression test is done to determine whether or not the effect of product quality (X1), service quality (X2) and price (X3) to customer satisfaction (Y). The above table can compare the magnitude of P-Value on the sig column with a significant of 0.05 with the following hypothesis:

$Y=-3,101+0,394 X_{1}+0,216 X_{2}+0,287 X_{3}$

$\mathrm{R}=0,930 \mathrm{~F}=249,890$

The regression equation can be interpreted as follows:

1. If the constant of 3.101 means product quality (X1), service quality (X2) and price (X3) value is 0 and customer satisfaction has a value of 3.101 assuming other variable variables are considered fixed.

2. The regression coefficient of product quality variable (X1) is 0,394 meaning that if other independent variable is fixed value and product quality increases by 1 unit, then customer satisfaction will increase by 0,394 .

3. Coefficient of regression of service quality variable (X2) equal to 0,216 meaning that if other independent variable is fixed value and service quality increase by 1 unit, hence customer satisfaction will experience increase equal to 0,216 .
4. The coefficient of variable price regression (X3) equal to 0.287 means that if other independent variables are fixed and the price increases by 1 unit, then the customer satisfaction will increase by 0.287 .

5. In the above equation can be seen that each - each coefficient is positive value means a positive relationship between independent variables with dependent variable. If the independent variable is increasingly fed its dependent variable will also menagalami increase assuming other variable variables remain.

Determination Coefficient Test

Table 2 : Coefficient Determination

Model Summary

\begin{tabular}{|c|c|c|c|c|}
\hline $\begin{array}{c}\mathrm{M} \\
\text { odel }\end{array}$ & $\mathrm{R}$ & $\begin{array}{c}\mathrm{R} \\
\text { Square }\end{array}$ & $\begin{array}{c}\text { Adjusted } \mathrm{R} \\
\text { Square }\end{array}$ & $\begin{array}{c}\text { Std. Error of the } \\
\text { Estimate }\end{array}$ \\
\hline 1 & $\begin{array}{c}930 \\
\mathrm{a}\end{array}$ & .865 & .862 & 2.14611 \\
\hline
\end{tabular}

1. Predictors: (Constant), Price, Quality Services, Product Quality

2. Dependent Variable: Customer Satisfaction

In the above table adjusted R Square value of 0.862 , this can be interpreted that the variable quality of product, service quality and price to customer satisfaction of $86 \%$ while the remaining percentage is the influence of other variables that are not included in this study.

Table 3 : Results of t-Test

Coefficients $^{\mathrm{a}}$

\begin{tabular}{|c|c|c|c|c|c|c|}
\hline \multicolumn{2}{|c|}{ Model } & \multicolumn{2}{|c|}{$\begin{array}{l}\text { Unstandardized } \\
\text { Coefficients }\end{array}$} & \multirow{2}{*}{$\begin{array}{l}\text { Standardized } \\
\text { Coefficients } \\
\text { Beta }\end{array}$} & \multirow[t]{2}{*}{$\mathrm{t}$} & \multirow[t]{2}{*}{ Sig } \\
\hline & & B & $\begin{array}{l}\text { Std. } \\
\text { Error }\end{array}$ & & & \\
\hline & (Constant) & -3.101 & 1.200 & & $\begin{array}{l}-2.58 \\
4\end{array}$ & $\begin{array}{l}.01 \\
1\end{array}$ \\
\hline & $\begin{array}{l}\text { Product } \\
\text { Quality }\end{array}$ & .394 & .065 & .439 & 6.023 & $\begin{array}{l}.00 \\
0\end{array}$ \\
\hline & $\begin{array}{l}\text { Service } \\
\text { Quality }\end{array}$ & .216 & .048 & .286 & 4.524 & $\begin{array}{l}.00 \\
0\end{array}$ \\
\hline & Price & .287 & .077 & .261 & 3.747 & $\begin{array}{l}.00 \\
0\end{array}$ \\
\hline
\end{tabular}

t-Test

a. Dependent Variable: Customer Satisfaction

From the table above can be interpreted as follows :

Ho: There is no effect of product quality on customer satisfaction

Hi: There is influence of product quality to customer satisfaction

In this hypothesis test, will test the initial hypothesis and comparative hypothesis as follows:

Accept Ho: if the calculation significance level is above $\alpha=5 \%$

Accept Hi: If the significant level of calculation below $\alpha \quad=5 \%$

In the table above can be seen for product quality 
variable $(\mathrm{X} 1)$ has a t value of 0.000 is smaller than 0.05 then Ho is rejected and Hi accepted. So it can be concluded that product quality variables have an influence on customer satisfaction. Service quality variable (X2) has a value of $t$ count 0.000 smaller than 0.05 then $\mathrm{Ho}$ is rejected and $\mathrm{Hi}$ accepted. So it can be concluded that the variable quality of service there influence on customer satisfaction. The price variable (X1) has a t value of 0,000 greater than 0.05 then Ho is rejected and Hi accepted. So it can be concluded that the price variable there influence on customer satisfaction.

\section{Model Reliability Test}

Table 4 : Result Model Reliability Test

ANOVA $^{\mathrm{a}}$

\begin{tabular}{|l|l|l|l|l|l|}
\hline Model & $\begin{array}{l}\text { Sum of } \\
\text { Squares }\end{array}$ & df & $\begin{array}{l}\text { Mean } \\
\text { Square }\end{array}$ & F & Sig. \\
\hline 1Regression & $\begin{array}{l}3452.81 \\
1\end{array}$ & 3 & $\begin{array}{l}1150.93 \\
7\end{array}$ & $\begin{array}{l}249.89 \\
0\end{array}$ & $\begin{array}{l}.000 \\
\mathrm{~b}\end{array}$ \\
Residual & $\begin{array}{l}538.875 \\
\text { Total }\end{array}$ & $\begin{array}{l}11 \\
7\end{array}$ & 4.606 & & \\
& $\begin{array}{l}3991.68 \\
6\end{array}$ & $\begin{array}{l}12 \\
0\end{array}$ & & & \\
\hline
\end{tabular}

1. Dependent Variable: Customer Satisfaction

2. Predictors: (Constant), Price, Service Quality, Product Quality

Based on the results of the model reliability test in the above table, then by using $\alpha=5 \%$ explanation can be given is the simultaneous test of all variables obtained $\mathrm{F}$ value counted 249,890 with significance level much smaller than 0.05 that is 0.000 , it can be concluded that kualias product, service quality and price together affect customer satisfaction.

\section{CONCLUSION}

Based on the research and discussion during the period of research on product quality, service quality and price to customer satisfaction Indosat Ooredoo, the following conclusion of observations that have been raised in the previous chapter are as follows:

1.Product quality partially affects Indosat Ooredoo customer satisfaction.

2.Service quality partially affects Indosat Ooredoo customer satisfaction.

3.Price partially affects Indosat Ooredoo customer satisfaction.

4.Product quality, service quality and price simultaneously affect the customer satisfaction of Indosat Ooredoo.

\section{G. Suggestions}

For the next researcher, it is hoped to be able to add other variables outside of the research to get more varied result in its effect on customer satisfaction, besides it is also expected to research in different location to see comparison of the result.

Ethical clearance - Not required

Source of funding- Self

Conflict of Interest - Product Quality, Quality Services, Price toward Customer Satisfaction at Indosat Ooredoo

\section{References}

[1] Fandy Tjiptono. Pemasaran Jasa. Yogyakarta : Andi, 2014.

[2] Ghozali, Imam. Aplikasi Analisis Multivariate Dengan Program SPSS. Semarang : Badan Penerbit Universitas Diponegoro, 2009.

[3] Kotler, Philip dan Amstrong. Management Pemasaran. Jakarta : PT. Prenhalindo, 2008.

[4] Rambat Lupiyoadi. Manajemen Pemasaran Jasa. Jakarta. Salemba Empat, 2014.

[5] Riduwan. Dasar - Dasar Statistika. Bandung: Penerbit Alfabeta, 2014.

[6] Sugiyono . Metode Penelitian Kombinasi (MIXED METHODS). BANDUNG:ALFABETA, 2015. 